\title{
Faktor Ideasi Dalam Proses Kreasi Seniman Lukis Jelekong
}

\author{
Uzda Nabila Shabiriani ${ }^{1}$, Deny Willy Junaidy ${ }^{2}$, Pindi Setiawan ${ }^{3}$ \\ ${ }^{1}$ Magister Desain, Fakultas Seni Rupa dan Desain, Institut Teknologi Bandung, Jalan Ganesha 10, Bandung, \\ 40132, Indonesia
}

${ }^{2}$ Kelompok Keahlian Manusia dan Ruang Interior, Fakultas Seni Rupa dan Desain, Institut Teknologi Bandung, Gedung CADL lantai 6, Jalan Ganesha 10, Bandung, 40132, Indonesia

${ }^{3}$ Kelompok Keahlian Komunikasi Visual dan Multimedia, Fakultas Seni Rupa dan Desain, Institut Teknologi Bandung, Gedung CADL lantai 6, Jalan Ganesha 10, Bandung, 40132, Indonesia

'uzdanabila@students.itb.ac.id

\begin{abstract}
Alih keterampilan yang dilakukan secara turun-temurun dalam komunitas pelukis Jelekong yang tidak memiliki latar belakang pendidikan seni formal telah berlangsung selama 50 tahun dan menghasilkan karakter khas dari lukisan Jelekong yang secara konsisten dipraktekkan dalam memproduksi karya lukis. Tujuan penelitian ini adalah untuk mengetahui faktor ideasi seniman lukis Jelekong yang tidak memiliki latar belakang pendidikan seni formal agar membangun pemahaman mengenai proses kreasi pada konteks pewarisan keahlian melukis secara turun-temurun. Penelitian ini menganalisis proses kreasi pada ideasi tahap awal dengan metode verbal report, melalui analisis jaringan konsep asosiatif dari pengalaman subjek saat menggambar sketsa, image analysis dan analisis faktor. Dari hasil analisis, 10 pelukis Jelekong yang diteliti dalam pikirannya saat proses menggambar sketsa mengarah kepada harmoni yang diindikasikan melalui jarak rumah yang berdekatan, penempatan objek yang umumnya berjumlah dua di sisi kanan dan kiri, perbedaan warna objek jauh dan dekat, alam yang ideal dengan adanya awan, bentuk figuratif dan benda alam lainnya, perbedaan garis untuk memberikan tekstur, perbedaan profesi, perbedaan aktifitas, serta komposisi yang seimbang. Ketika menggambar sketsa, pelukis juga mempertimbangkan ketenangan yang diindikasikan melalui suasana yang sepi dengan tidak adanya unsur alam yang rusak, seperti kekeringan namun suasana yang sejuk, ingatan seniman akan suasana alam yang sejuk dan tenang, serta gambar-gambar dengan ruang yang luas, seperti penggambaran satu rumah dan sangat jarang menggambar banyak makhluk hidup. Faktor ideasi dalam proses kreasi seniman lukis Jelekong cenderung mempraktikkan peniruan atau mencontoh karya yang telah dibuat sebelumnya dan sangat jarang ditemukan unsur kebaruan, sehingga seringkali menemukan harmoni dan ketenangan pada setiap karya.
\end{abstract}

Kata kunci: jelekong, ideasi, proses kreasi, kreativitas.

\section{Ideation Factor In The Creation Process Of Jelekong Painting Artists}

Jelekong painters community transferred their knowledges to generations by hereditary who do not have formal art education background because unlike the creation process (formally) learned in university, Jelekong painting artists could have their own understanding of such concept. This research aims to determine the ideation factor in the creation process of Jelekong painting artists who do not have formal art education background to build an understanding of creation process in the context of hereditary painting knowledges. The creation process at early stage of the idea analyzed using verbal report method, though an associative concept network analysis of subject's experience when drawing sketches, image analysis and factor analysis. From the data analysis results, 10 Jelekong painting artists examined in their minds when the drawing sketches process leads to harmony indicated by the distance close of houses, the object placement generally amount to two on the right and left, the different colors of distant and near objects, the ideal natural landscape with clouds, figurative shapes and other natural objects, sung the different lines to give texture, different professions, different activities, and balanced composition. When drawing sketches, the painters also considers the serenity that is indicated through a quiet atmosphere in the absence of damaged natural elements, such as drought but cozy atmosphere, painters' memories of a cozy and quite natural atmosphere, pictures with a large space, as if there is only one house and extremely rare draw many living things. The ideation factor in the creation process of Jelekong painting artists tends to practice imitating or copying works that have been made before and really 
rare to find the element of novelty that causes harmony and serenity factors frequently found in each works.

Keywords: jelekong, ideation, creation process, creativity.

Proses Review : 18 - 31 Agustus 2020, Dinyatakan Lolos: 7 September 2020

\section{PENDAHULUAN}

Bandung merupakan salah satu kota kreatif yang memiliki banyak perguruan tinggi formal di bidang seni dengan metode pembelajaran yang terstruktur. Selain itu, terdapat pula kelompok masyarakat yang mengajarkan seni lukis secara turun-temurun kepada anak, cucu, dan kerabat dekat yang tidak memiliki bakat di bidang seni lukis, yaitu masyarakat Jelekong. Alih keterampilan ini telah berlangsung selama 50 tahun dalam komunitas seniman lukis Jelekong yang tidak memiliki latar belakang pendidikan formal yang kemudian diturunkan kepada pelukis muda yang juga tidak memiliki latar belakang pendidikan seni yang menghasilkan karakter khas dari lukisan Jelekong yang secara konsisten dipraktikkan dalam memproduksi karya lukisnya. Oleh karena itu peneliti tertarik untuk melakukan penelitian mengenai proses kreasi seniman lukis Jelekong.

Jelekong dikenal memiliki ragam seni dan budaya, seperti kerajinan wayang golek, pencak silat, pertunjukan musik tradisional, tari jaipong dan seni lukis. Kesenian-kesenian tersebut masih terus dijaga hingga saat ini dengan adanya pementasan wayang golek, pertunjukan musik tradisional dan tari jaipong yang disesuaikan dengan permintaan pengunjung dan pementasan ini dilakukan di padepokan Giri Harja. Selain itu, masyarakat juga tetap aktif melukis di rumah masing-masing untuk memproduksi lukisan setiap hari, serta ada pula masyarakat yang hanya melukis sesuai dengan permintaan konsumen.

Masyarakat Jelekong banyak yang beralih profesi dari petani menjadi pelukis karena melihat besarnya peluang seni lukis dan menyebabkan terus bertambahnya jumlah pelukis di Jelekong. Saat ini terdapat lebih dari 1000 pelukis yang tetap aktif melukis, jumlah tersebut didominasi oleh pelukis muda yang telah melukis lebih dari 5 tahun dan berusia kurang dari 30 tahun. Ada pula pelukis yang beralih profesi menjadi penghasil pigura dikarenakan melihat besarnya peluang pasar kanvas dan pigura Jelekong yang semakin meningkat.

Lukisan Jelekong yang dihasilkan saat ini menampilkan corak lama yang telah dilukis sejak dahulu, yaitu pemandangan dan juga terdapat corak baru yang mengikuti tren di masyarakat. Keragaman corak yang dilukiskan dapat menunjukkan adanya perkembangan lukisan Jelekong yang disesuaikan dengan permintaan pasar. Kosyim
(2019) mengatakan, lukisan Jelekong terus berkembang dari segi corak dan teknik melukisnya. Jika dahulu corak yang dibuat berupa pemandangan, buah-buahan, hewan dan bunga, saat ini muncul lukisan wajah dan kaligrafi yang telah dilukis sejak tahun 2014. Sedangkan dari segi teknik melukis, dahulu hanya ada teknik natural dengan menggunakan kuas, namun saat ini terdapat teknik lainnya, seperti menggunakan pisau palet dan spons.

Terkait corak yang dilihat pada lukisan Jelekong, seringkali menampilkan objek gambar berupa gunung dan sawah, pasar Bali, bunga, ikan koi, harimau, kuda, ayam varis, ayam sabung, kaligrafi dan abstrak, tampaknya terkait dengan pola gambar yang telah dimiliki pelukis dan kebiasaan pelukis dalam melukis objek-objek tersebut yang dapat dilihat dari banyaknya persamaan objek gambar yang dilukiskan. Selain itu, terdapat pula objek gambar lain berupa foto wajah dan figur, tampaknya terkait proses imitasi dari referensi digital yang dimiliki pelukis. Ada satu pelukis yang menggunakan wajah wayang golek dalam setiap lukisan figurnya, sehingga masyarakat setempat menyebutnya sebagai pelukis kreatif dan hasil lukisannya disebut dengan lukisan kreatif.

Keahlian melukis yang diajarkan secara turun-temurun oleh Odin Rohidin tidak terjadi di ruang pembelajaran yang terstruktur, melainkan terjadi secara langsung dan berdasarkan pengalaman pelukis-pelukis yang telah belajar sebelumnya. Para pelukis membiarkan anak dan cucunya ikut berpartisipasi dalam kegiatan melukis sejak kecil dengan memberikan kanvas kecil, kuas dan cat minyak. Biasanya mereka akan meniru gambar yang dilukis orang tuanya di kanvas, meskipun gambar yang dihasilkan tidak sesuai dengan objek yang dilukis orang tuanya dan seringkali menjadi objek yang abstrak. Kegiatan ini terus-menerus dilakukan hingga hasil lukisannya serupa dengan hasil lukisan pelukis yang telah lama melukis. Proses regenerasi yang berjalan secara alami menyebabkan keahlian melukis di Jelekong dapat bertahan hingga saat ini.

Proses kreatif merupakan proses menghasilkan ide-ide baru dalam pembuatan karya, yang mana di dalamnya terdapat tahapan-tahapan untuk menghasilkan sebuah karya baru yang berbeda dari sebelumnya, mulai dari tahap empathize, define, ideate, prototype hingga test. Dalam penelitian ini, peneliti hanya terfokus kepada tahap ideasi yang mendorong berbagai ide yang muncul seluas mungkin untuk dapat dipilih dan bukan hanya sekedar menemukan 
solusi. Tahap ideasi dalam proses kreasi seniman lukis Jelekong terletak pada proses menggambar sketsa, yang mana proses ini merupakan tahap awal dari proses melukis di Jelekong dan bagian kecil dari proses kreatif yang biasa disebut dengan proses kreasi. Proses ini mampu menangkap ide-ide yang dituangkan seniman lukis Jelekong dalam menciptakan karya lukisnya.

Peneliti melihat proses kreasi yang dilakukan seniman lukis Jelekong merupakan proses imitasi dari berbagai konsep imaji, baik dari pembayangan (representasi mental) maupun referensi imaji digital. Dari berbagai sumber imaji ini, diduga para pelukis juga mengalami proses sintesa mental dasar (mental sintesis). Tujuan penelitian ini adalah untuk mengetahui faktor ideasi seniman lukis Jelekong yang tidak memiliki latar belakang pendidikan seni formal agar membangun pemahaman mengenai proses kreasi pada konteks pewarisan keahlian melukis secara turun-temurun.

Penelitian ini dibingkai oleh literatur yang terkait dengan representasi mental, sintesis mental, kriteria keindahan kerajinan rakyat, representasi kognitif lukisan dan pembelajaran berdasarkan tindakan. Kelima literatur tersebut digunakan dalam analisis verbal dan gambar sketsa pelukis Jelekong. Teori representasi mental (Finke, 1980: 113-132) untuk menjelaskan proses kognisi dalam konteks kreatif yang ada pada individu tergantung pada pola pikir individu tersebut, yang mana pola pikir tersebut didasari oleh ingatan individu akan suatu objek. Hasil dari proses kognisi tersebut dapat berupa objek yang digambarkan sesuai dengan ingatan individu (recalling), maupun penggabungan antara hasil ingatan individu (recalling) dengan referensi imaji digital yang dapat menghasilkan objek gambar kreatif dan tidak, yang biasa disebut sebagai sintesis mental (Finke, 1988: 252-257). Gambar sketsa yang dihasilkan melalui percobaan menggambar sketsa dianalisis dengan menggunakan tiga tingkatan dalam representasi kognitif lukisan yang dijelaskan oleh Solso (Loughlin, 2015: 257-293), serta delapan kriteria keindahan dari teori Mingei (Kikuchi, 2004: 52-58) dan estetika Barat (Read dalam Triyanto, 2015) yang telah dimodifikasi. Kemudian untuk menjelaskan proses alih pengetahuan yang dilakukan secara turun temurun oleh pelukis Jelekong yang tidak memiliki background pendidikan seni dijelaskan menggunakan teori pembelajaran tindakan (Serrat, 2017: 589594).

Hasil penelitian ini diharapkan mampu membangun pemahaman mengenai proses kreasi pada konteks pewarisan keahlian melukis secara turun-temurun, mendokumentasikan adanya pewarisan keahlian melukis secara turun-temurun di Jelekong, dijadikan sebagai referensi proses kreasi pada konteks pewarisan keahlian, serta sebagai pelestarian kesenian lukis Indonesia di masa depan.

\section{METODE PENELITIAN}

Tujuan penelitian ini adalah untuk mengetahui faktor ideasi seniman lukis Jelekong yang tidak memiliki latar belakang pendidikan seni formal agar membangun pemahaman mengenai proses kreasi pada konteks pewarisan keahlian melukis secara turun-temurun. Sebagai tahap awal, peneliti melakukan klasifikasi terhadap berbagai macam karya lukis Jelekong, yaitu lukisan pemandangan gunung dan sawah, pasar Bali, pemandangan laut, bunga, ikan koi, harimau, kuda, ayam sabung, kaligrafi, profil atau figur dan wajah, ayam varis dan abstrak. Setiap karya disortir berdasarkan tema yang sering dilukiskan dan diklasifikasikan ke dalam sembilan kategori, yakni lukisan pemandangan, pasar Bali, bunga, ikan koi, harimau, kuda, ayam sabung, ayam varis dan abstrak.

Dari kesembilan kategori, peneliti mempertimbangkan tiga jenis lukisan untuk digunakan dalam percobaan menggambar sketsa, yaitu lukisan pemandangan, harimau dan abstrak. Ketiganya memiliki persamaan dalam menggambarkan objek gambar yang berbeda di setiap lukisan, namun peneliti memilih lukisan pemandangan sebagai objek penelitian yang digunakan dalam percobaan menggambar sketsa karena hanya lukisan pemandangan yang menunjukkan adanya sintesa tahap awal dan merupakan lukisan khas Jelekong. Peneliti menyatukan empat puluh lima lukisan pemandangan dengan objek gambar yang berbeda-beda dan melakukan pengamatan pada setiap objek yang dilukiskan.

\section{Prosedur Percobaan Menggambar Sketsa}

Untuk membuktikan adanya sintesa tahap awal dalam proses kreasi seniman lukis Jelekong, peneliti menyusun sebuah percobaan menggambar sketsa yang merupakan tahap awal proses konseptualisasi ide dalam menghasilkan sebuah karya. Peneliti menggunakan media kertas A2 dan pensil 2B untuk mempersingkat waktu pengerjaan dan tetap dapat menggambar setiap detail objek dengan baik. Setiap pelukis hanya diberikan waktu sepuluh sampai lima belas menit untuk menggambar sketsa dan

dilakukan secara bergantian. Peneliti memberikan beberapa instruksi terkait dengan aturan-aturan yang harus ditaati selama proses percobaan berlangsung maupun jika ada pelukis yang dapat menyelesaikan gambarnya sebelum batas waktu yang ditentukan, serta adanya penentuan objek-objek yang hanya boleh digambarkan. Peneliti menggunakan sepuluh pelukis yang terdiri dari lima pelukis senior yang telah melukis lebih dari dua puluh tahun dan lima pelukis junior yang telah melukis lebih dari lima tahun.

Peneliti telah menentukan dua belas objek yang boleh digambarkan untuk membentuk lukisan pemandangan, yaitu gunung, sawah, orang, pohon, saung, hewan, air terjun, tebing, laut, perahu, awan dan matahri. Dua belas objek tersebut dipilih berdasarkan objek-objek yang seringkali 
muncul dalam lukisan pemandangan. Para pelukis hanya dapat menggabungkan tiga sampai tujuh objek dalam karyanya yang dirasa cukup untuk memberikan stimuli dalam memunculkan ide kreatif. Selama proses menggambar sketsa sedang berlangsung, peneliti merekam seluruh rangkaian proses menggunakan kamera DSLR yang diletakkan di depan pelukis dengan jarak satu meter dan menggunakan tripod.

\section{Prosedur Verbal Protokol (Verbal Report)}

Untuk mengetahui signifikasi kreatif dari proses menggambar sketsa, peneliti membiarkan pelukis mengungkapkan ide gambarnya secara bebas dan tanpa batasan waktu. Namun pelukis tidak aktif dalam memberikan verbal report, sehingga peneliti memberikan beberapa pertanyaan untuk merangsang pelukis dalam menceritakan idenya lebih detail. Selama proses ini berlangsung, peneliti merekam seluruh ucapan pelukis dengan menggunakan perekam audio melalui smartphone.

Hasil verbal report ditranskripsikan dan disortir dengan membuang penjelasan yang tidak relevan, seperti adanya penjelasan yang tidak sesuai dengan konteks penelitian, serta penjelasan tambahan dari teman pelukis maupun ungkapan candaan. Peneliti hanya mengambil penjelasan yang dibutuhkan dan diterjemahkan ke dalam bahasa Inggris. Dari seluruh rangkaian ucapan pelukis, peneliti hanya mengambil kata benda untuk menggambarkan struktur memori sebagai sistem yang memiliki asosiatif dengan ide tunggal, namun memiliki banyak makna. Data verbal diolah menggunakan analisis jaringan konsep asosiatif (ACNA).

\section{Metode Analisis Jaringan Konsep Asosiatif (ACNA)}

Metode analisis jaringan konsep asosiatif (ACNA) merupakan cara menggali kesan yang didapatkan oleh individu terhadap objek melalui kata-kata yang dihitung dengan analisis jaringan dan memanfaatkan data kamus asosiatif USF Norms. Analisis jaringan konsep asosiatif dijadikan sebagai protokol baru dalam menggali kesan mendalam individu terhadap sebuah objek. Makna laten berupa kesan mendalam yang sulit terungkap secara verbal dapat dimunculkan dalam bentuk struktur jaringan asosiasi kata. Kesan awal yang terucap perlu dianalisis lebih lanjut untuk mendapat makna laten yang tidak terungkap.

Untuk mengevaluasi kata-kata verbal yang diucapkan pelukis, peneliti menggunakan analisis verbal sebagai bagian dari protokol analisis yang merupakan hasil dari proses berpikir. Seniman lukis Jelekong sebagai subjek penelitian diinstruksikan untuk mengekspresikan idenya melalui verbal pada tahap awal proses kreatif. Ide yang diungkapkan secara verbal menunjukkan kesan awal pelukis, kemudian ditinjau lebih dalam menggunakan metode analisis jaringan konsep asosiatif yang dihitung dengan analisis jaringan yang didasarkan pada konsep kamus asosiatif.
Peneliti mengekstraksi kata benda untuk mendapatkan makna asosiatif dan nilai makna asosiatifnya berdasarkan kamus USF Norms, seperti seberapa besar ingatan pelukis akan masa kecil maupun lingkungannya yang dapat mempengaruhi gambar yang dihasilkan. Data numerik ditampilkan secara visual menggunakan software Pajek untuk mengetahui makna asosiatif yang memiliki nilai makna asosiatif tertinggi untuk mengetahui level proses kreatif seniman lukis Jelekong pada proses menggambar sketsa.

Metode dalam Menganalisis Gambar (Image Analysis) Peneliti melakukan analisis pada setiap objek gambar dalam sepuluh hasil gambar sketsa pelukis menggunakan model tiga tingkatan dalam representasi kognitif lukisan, serta teori mingei dan estetika Barat yang membentuk delapan kriteria keindahan yang telah dimodifikasi. Setiap objek dianalisis dan ditandai dengan menggunakan warna yang berbeda. Peneliti menemukan adanya lima belas pola gambar pada gambar sketsa yang membentuk lima belas kategorisasi dimensi dalam proses kreasi seniman lukis Jelekong, yakni placement, dimension, source of life, nature, element of nature, activity, thought, texture, culture, manmade, human relationship, characteristic, color, household needs, dan hobby.

\section{Metode dalam Menemukan Faktor Ideasi (Factor Analysis)}

Makna asosiatif berserta nilai makna asosiatif dari sepuluh objek disatukan dan disortir ke dalam lima belas dimensi yang telah didapatkan berdasarkan hasil image analysis pelukis. Setiap dimensi dibedakan berdasarkan warna untuk mempermudah peneliti dalam membaca setiap data yang didapatkan. Peneliti mengurutkan kata asosiatif dari nilai makna asosiatif tertinggi hingga terendah. Setiap dimensi diurutkan berdasarkan banyaknya kata asosiatif beserta nilai makna asosiatif yang didapatkan. Seluruh bobot atau nilai makna asosiatif pada masing-masing dimensi dijumlahkan untuk mendapatkan total nilai makna asosiatif dari setiap dimensi. Peneliti mereduksi kata-kata asosiatif berserta nilai makna asosiatifnya sebesar lima puluh persen dari setiap dimensi untuk mendapatkan data yang lebih terukur dan tidak memiliki jarak yang terlalu jauh antara satu dengan yang lain.

Untuk mengetahui faktor ideasi dalam proses kreasi seniman lukis Jelekong, peneliti menganalisis data reduksi berupa makna asosiatif berserta nilai makna asosiatifnya menggunakan software IBM Statistic 25. Data statistic yang dihasilkan berupa hasil tes varian (\%), total variance experienced dan rotated component matrix. Dari ketiga data tersebut, peneliti mendapatkan dua faktor yang terbentuk untuk menjelaskan faktor ideasi yang dihasilkan.

\section{ANALISIS FAKTOR IDEASI DALAM PROSES KREASI SENIMAN LUKIS JELEKONG}

Temuan Level Proses Kreasi Seniman Lukis Jelekong 
Selama analisis tahap awal, peneliti memperoleh 305 kata benda dari pemikiran verbal 10 pelukis Jelekog yang telah diurutkan berdasarkan urutan alfabet dan diberi nama subjek 1 - 10. 305 kata benda diekstrak untuk mendapatkan makna asosiatif masing-masing kata berdasarkan kamus asosiatif USF Norms. Berdasarkan hasil ekstraksi kata benda, 10 subjek pelukis menghasilkan 4445 kata-kata asosiatif, yang mana masing-masing subjek menghasilkan 320 - 480 kata-kata asosiatif. Selanjutnya, kata-kata asosiatif yang dihasilkan setiap subjek menghasilkan nilai-nilai korelasi antar makna asosiatif melalui software Pajek. Data numerik divisualisasikan menggunakan grafik jaringan konseptual yang dapat menampilkan kata-kata asosiatif tertinggi hingga paling rendah (lihat Gambar 1).

Peneliti mengambil satu sample dari kesepuluh grafik jaringan konseptual pelukis Jelekong, yaitu hasil analisis verbal subjek 1 untuk dijabarkan lebih detail mengenai data yang didapatkan melalui analisis verbal yang telah dilakukan. Pada tahap awal analisis subjek 1, peneliti memperoleh 24 kata benda dari pemikiran verbal pelukis yang telah diurutkan berdasarkan urutan alfabet (lihat Tabel 1). Dari 24 kata benda tersebut diekstrak untuk mendapatkan makna asosiatif berdasarkan kamus USF Norms dan subjek 1 menghasilkan 321 kata-kata asosiatif.

Tabel 1. Kata Benda dari Pemikiran Subjek 1 Diurutkan berdasarkan Alfabet

\section{Subjek 1 (24)}

Animal, Arrangement, Coziness, Deer, Focus, Food, Jungle, Leaf, Line, Location, Meaning, Number, Object, People, Problem, Scenery, Silence, Sketch, Skill, Title, Tree, Waterfall, Weed, Wild Boar.

Selanjutnya ekstraksi kata benda ini diproses menggunakan rumus Out-Degree Centrality (ODC) untuk mendapatkan nilai makna asosiatif tersebut. Sentralitas skor ODC mendeteksi semua node yang menunjukkan jumlah kata yang terkait dengan kata-kata stimulus. Nilai makna asosiatif yang dihasilkan subjek 1 mulai dari 0,00 sampai 0,14 dari berbagai kata-kata asosiatif dan data numerik yang dihasilkan, divisualisasikan menggunakan grafik jaringan konseptual menggunakan software Pajek (lihat Gambar 2). Hasil visualisasi menyajikan kata-kata asosiatif tertinggi hingga rendah dengan grafik visual.
Gambar 1. Visualisasi Jaringan Konseptual 10 Subjek

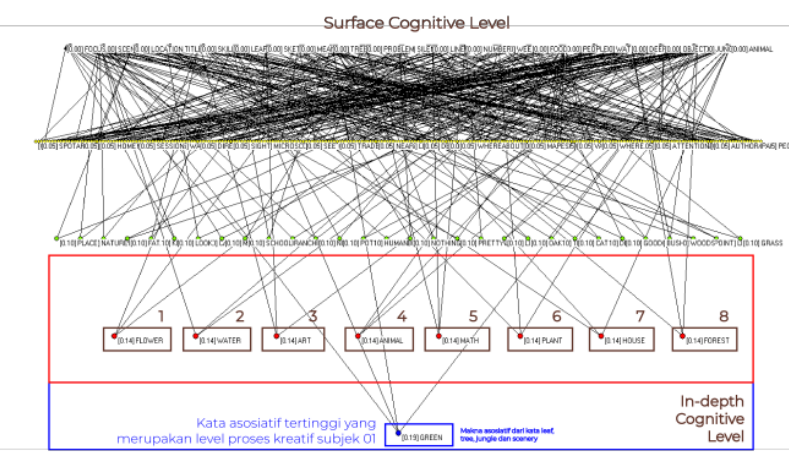

1. Makna asosiatif dari kata weed, leaf dan tree 5 Makna asosiatif dari kata problem. line, dan number 2. Makna asosiatif dari kata waterfall, soenery dan food 6 . Makna asosiatifif dari kata leaf, weed dan jun nle

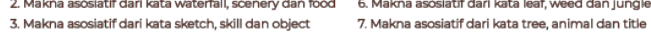
4. Makna asosiatif dari kata people, dear, dan jungle 8. Makna asosiatlf dari kata tree, Jungle dan deer
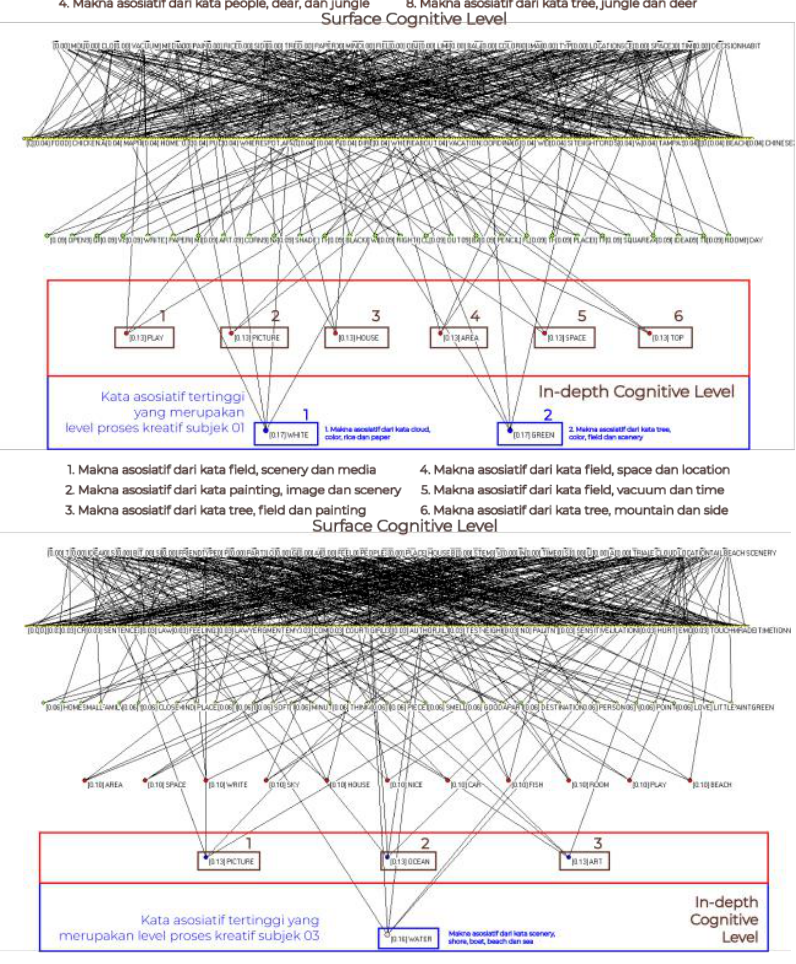

Makna asosiatif dari kata image, scenery, sketch dan painting 2 Makna asosiatif dari kata shore, beach, boat dan sea

3. Makna asosiatif dari kata object, painting, sketch dan detail
Surface Cognitive Level

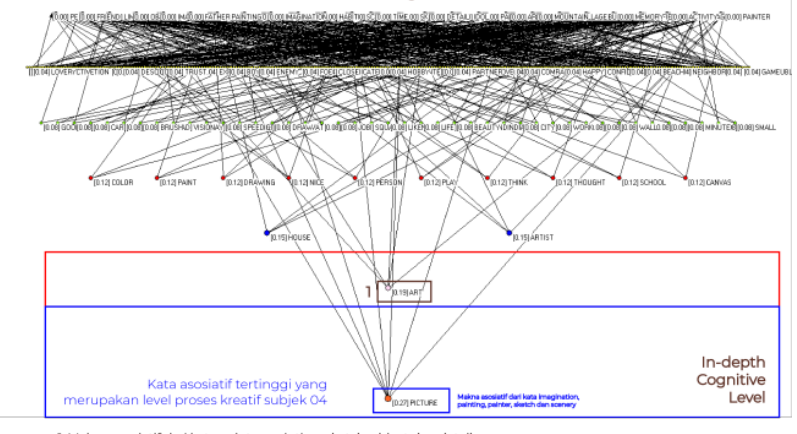

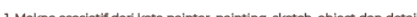



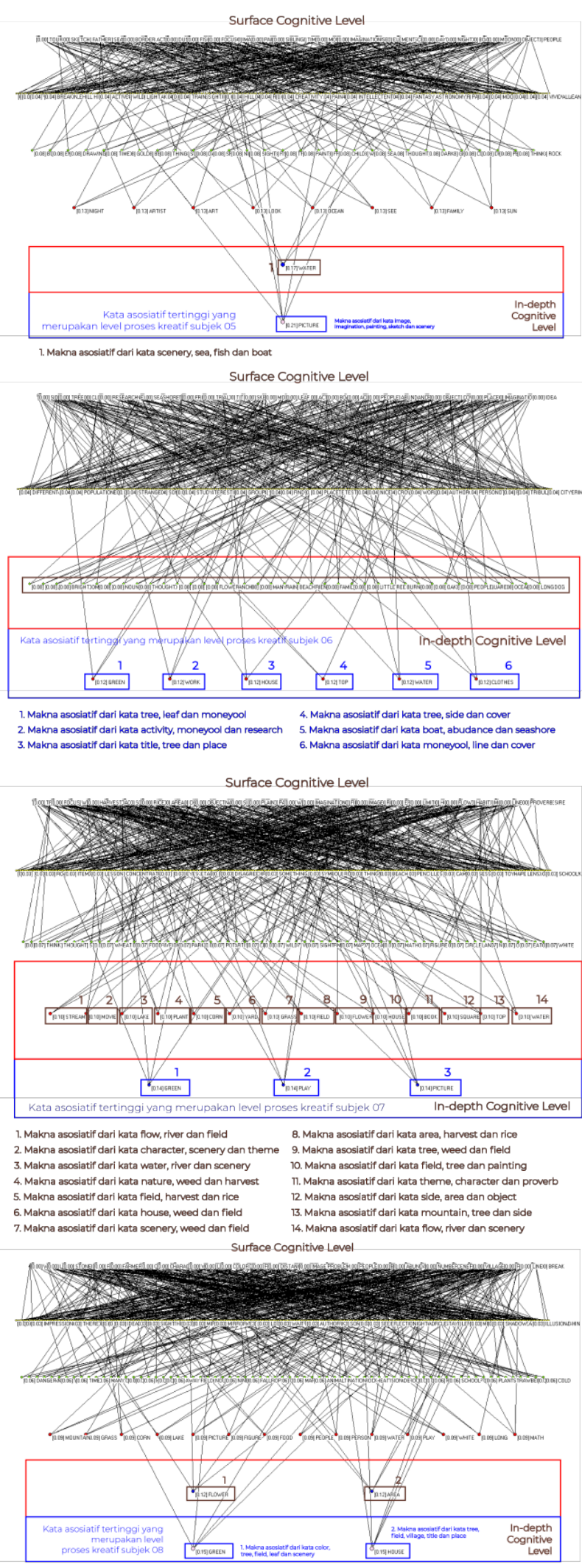

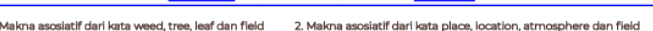
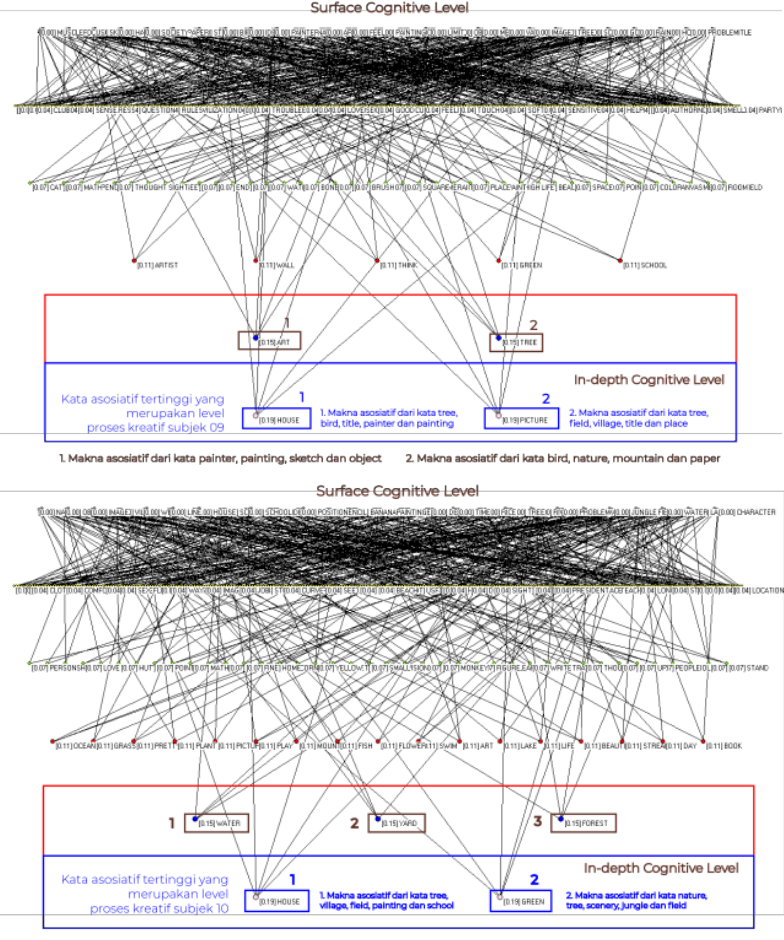

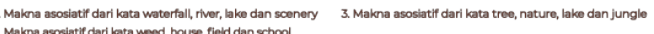

Gambar 2. Visualisasi Jaringan Konseptual Subjek 1

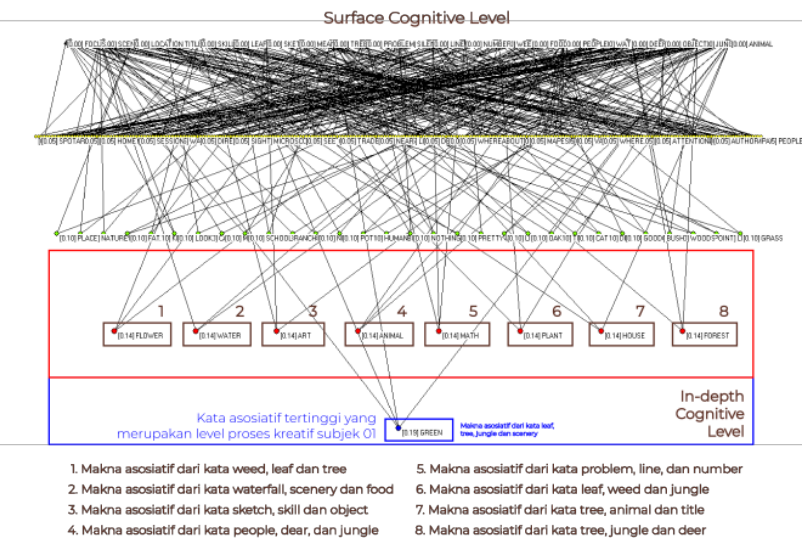

Berdasarkan visualisasi jaringan konseptual subjek 1, terdapat 5 tahapan dalam ekstraksi kata benda untuk menghasilkan level kognitif terdalam. Pada layer terbawah menampilkan makna asosiatif dengan nilai tertinggi yang menunjukkan level proses kreatif subjek 1, yakni green dengan nilai makna asosiatif sebesar 0,19. Kata green merepresentasikan pemikiran subjek 1 akan sesuatu yang hijau atau yang berhubungan dengan alam. Hal ini diperkuat dengan hasil analisis gambar sketsa subjek 1 yang menggambar hutan belantara, dimana subjek 1 membayangkan keheningan dan suasana sejuk hutan belantara yang membuatnya merasa senang dalam menggambar. Hasil ini juga diperkuat dengan ditonjolkannya penggambaran objek gambar pohon beringin yang menutupi ruang kosong kertas, hal ini dapat menunjukkan pemikiran pelukis akan sesuatu objek yang hijau. 
Visualisasi jaringan konseptual subjek 1 juga menampilkan makna asosiatif dengan nilai makna asosiatif cukup tinggi, yaitu sebesar 0,14 yang diberi warna merah pada layer ke 3. Kata flower merupakan makna asosiatif dari kata weed, leaf dan tree yang memiliki nilai makna asosiatif 0,00 . Kata water merupakan makna asosiatif dari kata waterfall, scenery dan food yang memiliki nilai asosiatif 0,00. Kata art merupakan makna asosiatif dari kata sketch, skill dan object yang memiliki nilai makna asosiatif 0,00 . Kata animal merupakan makna asosiatif dari kata people, dear dan jungle yang masing-masing memiliki nilai makna asosiatif 0,00 . Kata math merupakan makna asosiatif dari kata problem, line dan number yang memiliki nilai asosiatif 0,00 . Kata plant merupakan makna asosiatif dari kata leaf, weed dan jungle yang memiliki nilai makna asosiatif 0,00. Kata house merupakan makna asosiatif dari kata tree, animal dan title yang memiliki nilai makna asosiatif 0,00 . Kata forest merupakan makna asosiatif dari kata tree, jungle dan deer yang masing-masing memiliki nilai asosiatif 0,00 . Setiap kata-kata asosiatif memiliki hubungan antara satu dengan yang lainnya, sehingga menghasilkan makna asosiatif yang sama asosiasinya dengan kata-kata tersebut.

Korelasi level proses kreatif subjek 1 pada sesuatu yang hijau atau suasana alam diperkuat dengan nilai makna asosiatif tertinggi yang ditunjukkan dalam grafik, yaitu green. Kata green merupakan makna asosiatif dari kata leaf, tree, jungle dan scenery dengan nilai makna asosiatif sebesar 0,00. Jika melihat kata-kata asosiatif yang membentuk makna asosiatif green dapat dilihat bahwa kata-kata tersebut memiliki korelasi yang sama, yakni penggambaran akan hijaunya alam, sehingga level proses kreatif subjek 1 dipengaruhi oleh alam dengan seringnya subjek 1 melihat alam.

\section{Temuan Dimensi Pada Faktor Ideasi dalam Proses Kreasi Seniman Lukis Jelekong}

Berdasarkan hasil analisis gambar yang telah dilakukan sebelumnya, peneliti menemukan beberapa pola yang dihasilkan seniman lukis Jelekong dalam menggambar sketsa (lihat Gambar 3). Pola pertama, pelukis Jelekong seringkali menggambar objek pohon di sisi kanan dan kiri untuk memberikan fokus pada objek yang berada di tengah, baik objek tersebut sedang melakukan aktifitas maupun hanya ingin menonjolkan objek tersebut. Selain itu, penempatan objek pohon di sisi kanan dan kiri dapat memberikan kesan pelindung bagi objek lain di sekitarnya, sehingga objek lain merasa aman. Pola kedua, yaitu pelukis Jelekong seringkali menggambar objek berjumlah genap yang ditempatkan di sisi kiri, kanan, atas, maupun tengah. Hal ini dapat memberikan kesan keseimbangan pada gambar dan tidak terkesan berlebihan.

Pada pola ketiga, pelukis Jelekong seringkali menggambar unsur air, seperti air terjun dan aliran sungai di bagian tengah gambar yang dapat menunjukkan keutamaan air sebagai sumber kehidupan. Air merupakan salah satu elemen
Gambar 3. Hasil Image Analysis 10 Subjek
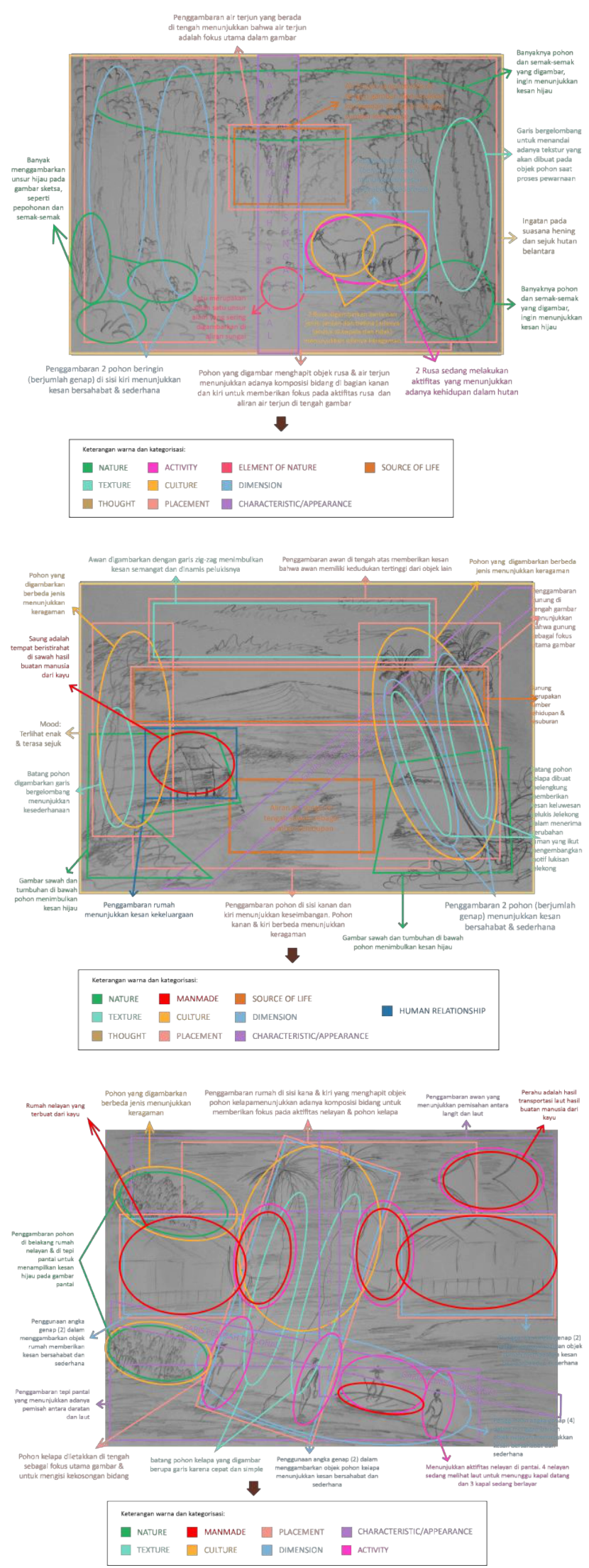

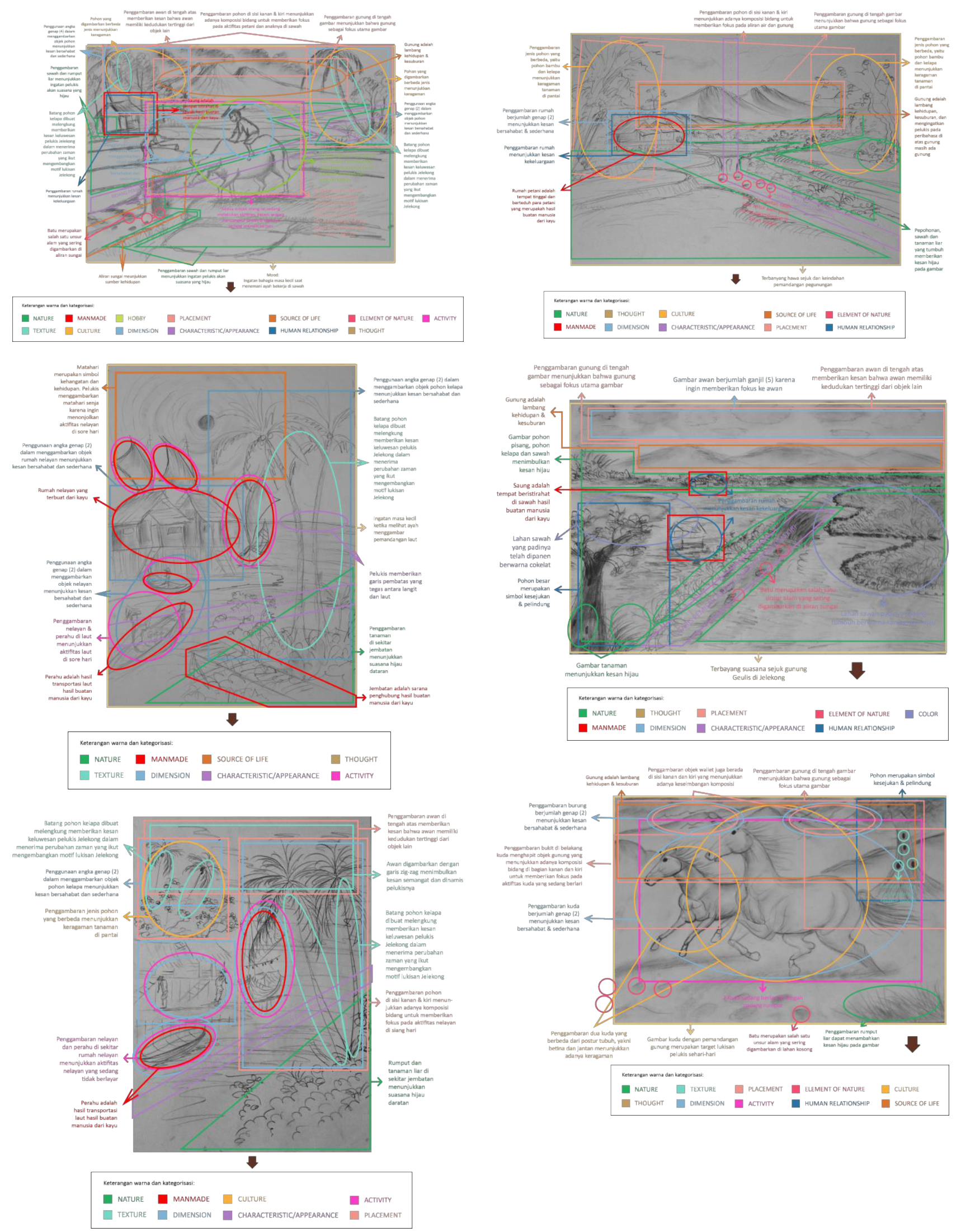


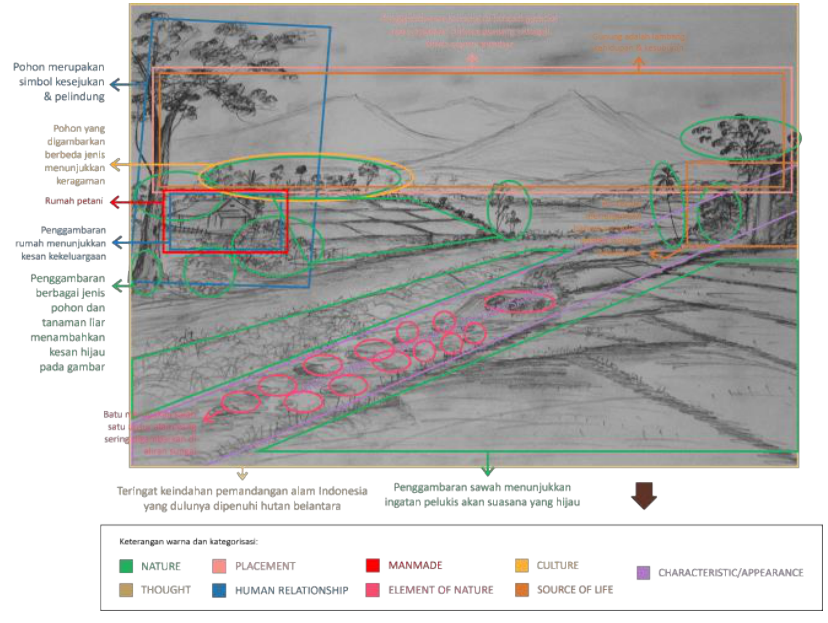

alam yang sangat berguna bagi manusia dalam menjalani kehidupan karena memiliki berbagai macam fungsi, yakni dalam mengairi sawah, industri, rumah tangga, rekreasi dan aktifitas lingkungan, tampaknya pelukis Jelekong ingin menampilkan keutamaan air bagi kehidupan manusia. Pola keempat, pelukis Jelekong seringkali menggambar objek pohon, rumput dan tanaman liar dalam gambar sketsanya yang dapat menimbulkan kesan hijau dalam gambar. Pola kelima, pelukis Jelekong seringkali menggambar objek batu pada aliran sungai dalam gambar sketsa pemandangan sawah dan gunung. Batu merupakan salah satu unsur alam yang seringkali didapatkan di sungai ataupun gunung. Berdasarkan hasil transkrip ucapan, pelukis menceritakan bahwa batu-batu tersebut merupakan batu yang jatuh dari air terjun yang mengikuti aliran air sehingga batu-batu tersebut mengendap di dalam air sungai.

Selanjutnya, pola kelima pelukis Jelekong seringkali menggambar objek hewan berjumlah dua yang dapat memberikan kesan berdampingan. Hal ini dapat terlihat dengan jelas pada gambar sketsa subjek 1 yang menggambarkan hutan belantara dengan objek hewan rusa. Rusa yang digambarkan berjumlah dua dan memiliki perbedaan fisik yang dapat menandakan adanya perbedaan kelamin, satu rusa digambar memiliki tanduk panjang di kepalanya yang menunjukkan bahwa rusa tersebut adalah rusa jantan, sedangkan rusa lainnya digambar tidak memiliki tanduk di kepalanya yang menunjukkan bahwa rusa tersebut adalah rusa betina.

Pola keenam, pelukis Jelekong seringkali menggambar objek makhluk hidup, yakni hewan dan manusia yang sedang melakukan aktifitas. hal ini dapat menunjukkan adanya kehidupan dalam gambar sketsa pemandangan. Pola ketujuh pelukis seringkali menggambar batang pohon hanya berupa garis bergelombang yang dapat menunjukkan kesan bahwa pelukis Jelekong ingin cepat menyelesaikan penggambaran objek tersebut, menyukai sesuatu yang sederhana dalam menggambar sketsa objek, atau pelukis berusaha memberikan tanda adanya tekstur pada objek tersebut yang nantinya akan diselesaikan saat proses pewarnaan. Pola kedelapan, pelukis seringkali menggam- bar pohon dengan jenis yang berbeda dalam satu gambar. Pohon-pohon yang digambar adalah pohon kelapa, albasiah, jati, cemara, cerme, mangga dan bambu yang dapat menimbulkan kesan adanya keberagaman dalam diri pelukis. Keragaman ini dapat berupa keragaman usia para pelukis, motif lukisan, maupun target lukisan setiap pelukis.

Pada pola kesembilan, pelukis seringkali menggambar objek hasil buatan tangan manusia, seperti perahu kayu, saung dan rumah petani yang berfungsi sebagai tempat tinggal, tempat beristirahat dan alat yang digunakan dalam melakukan pekerjaan sehari-hari. Pola kesepuluh, pelukis seringkali menggambar objek rumah, baik rumah yang berfungsi sebagai tempat tinggal, maupun saung yang berfungsi sebagai tempat beristirahat yang dapat memberikan kesan kekeluargaan pada diri pelukis. Berdasarkan hasil observasi ke Kampung Jelekong, peneliti menemukan para pelukis sangat akrab dan saling mengenal dengan baik satu sama lain. Selain itu, penampung lukisan juga membagi hasil penjualan kepada pelukis yang memberikan rekomendasi penampung tersebut ke wisatawan yang berkunjung ke Kampung Jelekong untuk membeli beberapa lukisan.

Selanjutnya, pola kesebelas pelukis seringkali menggambar objek gunung di tengah gambar, yang mana gunung merupakan sumber kehidupan dan kesuburan bagi area sawah di sekitarnya. Pola kedua belas pelukis seringkali menggambar garis pembatas yang membatasi antar sawah, langit dan lautan maupun daratan dan lautan. Garis pembatas ini terdiri dari garis vertikal dan diagonal yang dapat menimbulkan kesan adanya perbedaan unsur alam di setiap ruang. Pola ketiga belas, pelukis seringkali menggambar dua objek rumah yang saling berdekatan tanpa adanya jarak, hal ini dapat memberikan kesan adanya dua keluarga yang hidup berdampingan di diri pelukis.

Pola keempat belas belas, pelukis seringkali menggambar batang pohon kelapa melengkung yang dapat memberikan kesan 'luwes' pada diri pelukis Jelekong dalam menerima perubahan zaman yang ikut mengembangkan motif lukisan. Pola kelima belas, penggambaran satu pohon dapat ditemukan di beberapa hasil gambar sketsa pelukis Jelekong yang dapat memberikan kesan pelindung dan kesejukan bagi para pelukis. Dan pola terakhir, pelukis menggunakan warna yang berbeda pada objek sawah. Berdasarkan hasil transkrip ungkapan, pelukis ingin memberikan warna hijau dan kuning pada sawah yang sudah siap dipanen, sedangkan sawah yang telah dipanen diberikan warna cokelat.

Dari keenam belas pola yang telah disebutkan di atas, peneliti menemukan lima belas dimensi yang berbeda dalam proses kreatif seniman lukis Jelekong, yaitu placement, element of nature, source of life, activity, thought, texture, manmade, human relationship, color, nature, dimension, culture, household needs, characteristic dan hobby (li- 
Gambar 4. Kategorisasi Dimensi berdasarkan Hasil Image Analysis

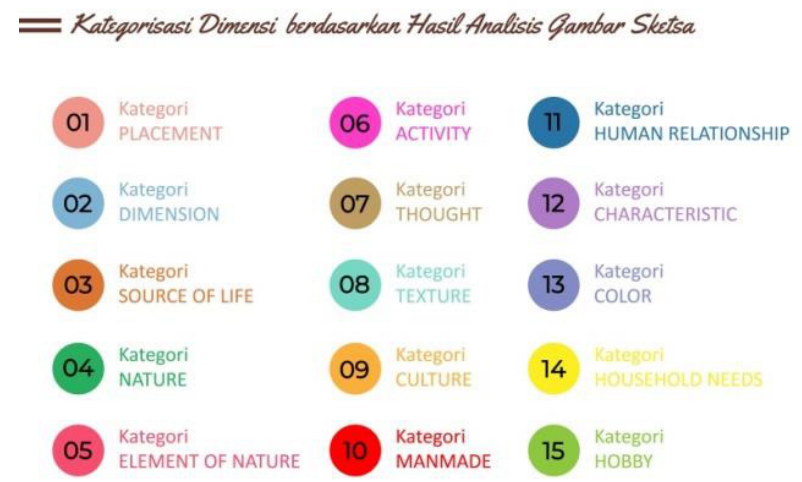

hat Gambar 4). Lima belas dimensi ini digunakan dalam analisis data verbal dan faktor proses kreatif seniman lukis Jelekong.

Dalam menganalisis gambar sketsa sepuluh subjek, peneliti menggunakan kriteria keindahan yang telah dimodifikasi dalam hasil gambar sketsa seniman Jelekong. Dari kesepuluh hasil gambar sketsa, peneliti melihat adanya dominasi keindahan kealamian, kesederhanaan dan fungsi yang sering ditonjolkan. Keindahan kealamian merepresentasikan objek gambar seniman berupa pemandangan alam dan sebagai objek yang digunakan dalam percobaan menggambar sketsa, maka kriteria keindahan ini seringkali muncul pada hasil gambar sketsa sepuluh pelukis. Keindahan kesederhanaan ditunjukkan dari adanya dua sampai tiga pola gambar, seperti penempatan pohon di sisi kanan dan kiri, penggunaan elemen hijau di setiap gambar dan garis pemisah vertikal maupun diagonal dalam gambar. Kemudian keindahan penggunaan/fungsi merepresentasikan fungsi dari hasil gambar sketsa seniman Jelekong sebagai elemen estetik yang dapat digunakan untuk menghias ruangan.

\section{Temuan Total Nilai dalam Dimensi pada Faktor Ideasi dalam Proses Kreasi Seniman Lukis Jelekong}

Berdasarkan nilai makna asosiatif tertinggi yang telah didapatkan dari masing-masing kata asosiatif, peneliti menyatukan data subjek 1 sampai 10 dan diurutkan berdasarkan nilai makna asosiatif tertinggi dari masing-masing subjek. Nilai makna asosiatif tertinggi dapat menunjukkan kata asosiatif yang paling banyak memiliki korelasi dengan kata asosiatif lain.

Kata-kata asosiatif dari masing-masing subjek disortir ke dalam lima belas kategori yang didapatkan dari hasil analisis gambar sketsa berdasarkan teori psikologis kognitif yang telah peneliti modifikasi, yaitu placement, element of nature, source of life, activity, thought, texture, manmade, human relationship, color, nature, dimension, culture, household needs, characteristic dan hobby. Peneliti membedakan setiap kategori dengan penggunaan warna yang berbeda-beda untuk mempermudah dalam pengelompokkan kata asosiatif. Tidak ada ketentuan warna dalam mengelompokkan setiap kelompok asosiatif, namun peneliti menggunakan warna dalam setiap kategori disesuaikan dengan warna yang digunakan pada analisa gambar sketsa pelukis.

Berdasarkan kategori yang telah dibuat, peneliti mendapatkan data kata asosiatif terbaru dari masing-masing kategori. Kategori manmade terdapat 198 kata-kata asosiatif, nature terdapat kata-kata asosiatif, activity terdapat 157 kata-kata asosiatif, source of life terdapat 113 kata-kata asosiatif, characteristic terdapat 86 kata-kata asosiatif, placement terdapat 76 kata-kata asosiatif, thought terdapat 66 kata-kata asosiatif, dimension terdapat 66 kata-kata asosiatif, element of nature terdapat 53 kata-kata asosiatif, household needs terdapat 46 kata-kata asosiatif, color terdapat 45 kata-kata asosiatif, culture terdapat 43 kata-kata asosiatif, texture terdapat 36 kata-kata asosiatif, hobby terdapat 28 kata-kata asosiatif, human relationship terdapat 13 kata-kata asosiatif, dan undefined terdapat 23 kata-kata asosiatif.

Peneliti mengurutkan kata-kata asosiatif berdasarkan nilai makna asosiatif tertinggi dan dari 3993 kata-kata asosiatif, peneliti hanya menggunakan 3993 kata-kata asosiatif dari 10 subjek penelitian. Kata asosiatif direduksi sebesar 50\% dari 3993 kata-kata asosiatif untuk mendapatkan data yang lebih terukur dan tidak terlalu memiliki banyak jarak satu dengan yang lain, sehingga peneliti hanya menggunakan 623 kata asosiatif dari lima belas kategori yang telah dipilih berdasarkan nilai makna asosiatif tertinggi. Kata-kata asosiatif disortir sesuai dengan kategori warna yang ada, yakni pink muda untuk placement, pink untuk element of nature, oranye untuk source of life, fushia untuk activity, cokelat untuk thought, biru muda untuk texture, merah untuk manmade, biru untuk human relationship, biru keunguan untuk color, hijau neon untuk nature, biru laut untuk dimension, oranye muda untuk culture, kuning untuk household needs, ungu untuk characteristic, hijau untuk hobby dan putih untuk undefined.

Setiap kata asosiatif yang dimasukkan ke dalam masing-masing kategori dapat mewakili kategori tersebut. Peneliti menempatkan kategori dengan kata asosiatif terbanyak berada di depan karena dapat mempermudah dalam membaca setiap data dan kata asosiatif pada masing-masing kategori diurutkan berdasarkan nilai makna asosiatif tertinggi. Peneliti menambahkan seluruh nilai makna asosiatif dari masing-masing kategori untuk mendapatkan nilai setiap kategori. Kategori manmade mendapatkan nilai 21.2684 dari total nilai korelasi makna asosiatif, nature mendapatkan nilai 16.0005 dari total nilai korelasi makna asosiatif, activity mendapatkan nilai 12.7891 dari total nilai korelasi makna asosiatif, source of life mendapatkan nilai 9.70085 dari total nilai korelasi makna asosiatif, characteristic mendapatkan nilai 6.52027 dari total nilai 
korelasi makna asosiatif, placement mendapatkan nilai 5.59263 dari total nilai korelasi makna asosiatif, thought mendapatkan nilai 4.89415 dari total nilai korelasi makna asosiatif, dimension mendapatkan nilai 5.76297 dari total nilai korelasi makna asosiatif, element of nature mendapatkan nilai 5.71655 dari total nilai korelasi makna asosiatif, household needs mendapatkan nilai 3.8097 dari total nilai korelasi makna asosiatif, color mendapatkan nilai 5.94494 dari total nilai korelasi makna asosiatif, culture mendapatkan nilai 4.593 dari total nilai korelasi makna asosiatif, texture mendapatkan nilai 5.9449 dari total nilai korelasi makna asosiatif, hobby mendapatkan nilai 2.37047 dari total nilai korelasi makna asosiatif, human relationship mendapatkan nilai 1.13839 dari total nilai korelasi makna asosiatif, dan undefined mendapatkan nilai 1.63806 dari total nilai korelasi makna asosiatif.

Berdasarkan penjabaran data nilai dari masing-masing-masing kategori, terdapat 5 kategori yang memiliki nilai paling tinggi, yaitu manmade, nature, activity, source of life dan characteristic. Peneliti mereduksi kata-kata asosiatif yang ada sebesar 50\% untuk mendapatkan data yang lebih terukur dan tidak terlalu memiliki banyak jarak satu dengan yang lain dan mendapatkan 623 kata asosiatif yang akan diproses dalam analisis faktor. Kata-kata asosiatif yang didapatkan dari setiap kategori disusun ulang berdasarkan banyaknya kata-kata asosiatif yang ada di masing-masing kategori. Pada kategori manmade, peneliti hanya menggunakan 99 kata asosiatif dengan nilai makna asosiatif dari 197 kata-kata asosiatif.

Pada kategori nature, peneliti hanya menggunakan 89 kata asosiatif dengan nilai makna asosiatif dari 176 kata-kata asosiatif. Pada kategori activity, peneliti hanya menggunakan 79 kata asosiatif dengan nilai makna asosiatif dari 157 kata-kata asosiatif. Pada kategori source of life, peneliti hanya menggunakan 57 kata asosiatif dengan nilai makna asosiatif dari 113 kata-kata asosiatif. Pada kategori characteristic, peneliti hanya menggunakan 40 kata asosiatif dengan nilai makna asosiatif dari 86 kata-kata asosiatif. Pada kategori placement, peneliti hanya menggunakan 36 kata asosiatif dengan nilai makna asosiatif dari 76 kata-kata asosiatif. Pada kategori thought, peneliti hanya menggunakan 34 kata asosiatif dengan nilai makna asosiatif dari 66 kata-kata asosiatif. Pada kategori dimension, peneliti hanya menggunakan 34 kata asosiatif dengan nilai makna asosiatif dari 66 kata-kata asosiatif. Pada kategori element of nature, peneliti hanya menggunakan 28 kata asosiatif dengan nilai makna asosiatif dari 53 kata-kata asosiatif. Pada kategori household needs, peneliti hanya menggunakan 24 kata asosiatif dengan nilai makna asosiatif dari 46 kata-kata asosiatif. Pada kategori color, peneliti hanya menggunakan 24 kata asosiatif dengan nilai makna asosiatif dari 45 kata-kata asosiatif. Pada kategori culture, peneliti hanya menggunakan 23 kata asosiatif dengan nilai makna asosiatif dari 43 kata-kata asosiatif. Pada kategori texture, peneliti hanya menggunakan 17 kata asosiatif dengan nilai makna asosiatif dari 36 kata-kata asosiatif. Pada kategori hobby, peneliti hanya menggunakan 15 kata asosiatif dengan nilai makna asosiatif dari 28 kata-kata asosiatif. Pada kategori human relationship, peneliti hanya menggunakan 9 kata asosiatif dengan nilai makna asosiatif dari 17 kata-kata asosiatif.

Hasil reduksi data dari masing-masing kategori disusun kembali ke dalam dua jenis tabel yang berbeda, yakni tabel yang berisikan kata-kata asosiatif dan skor ODC, serta tabel yang hanya berisikan skor ODC. Skor ODC yang didapatkan dari setiap kategori diproses menggunakan software IBM SPSS Statistic 25 untuk menganalisis faktor-faktor dalam proses kreatif Jelekong.

\section{Temuan Faktor Ideasi dalam Proses Kreasi Seniman Lukis Jelekong}

Berikut merupakan data yang akan dianalisis untuk mendapatkan faktor ideasi dalam proses kreasi seniman lukis Jelekong setelah dilakukannya sortir kata-kata asosiatif berdasarkan lima belas kategori, yakni manmade, nature, activity, source of life, characteristic/appearance, placement, thought, dimension, element of nature, household needs, color, culture, texture, hobby, dan human relationship.

Menurut KMO and Bartlett's Test, angka KMO MSA (Measure of Sampling Adequacy) $=0.882$, yakni 0.5, sample cukup atau layak. Nilai Approax. Chi-Square = 1092.481 dan signifikansi 0.000 terdapat korelasi antar variabel dan layak untuk proses lebih lanjut, sehingga jika nilai MSA pada "Anti Image Correlation” masing-masing $>0.5$ dalam seluruh variabel, maka nilai pada 15 kategori pelukis Jelekong dapat diproses lebih lanjut.

Berdasarkan hasil analisis faktor ditemukan hasil tes varian dalam presentase (lihat Tabel 2) yang dapat dijelaskan oleh faktor yang terbentuk berdasarkan "Eigenvalue: $>1$ ".

Tabel 2. Hasil Tes Varian 15 Dimensi

\begin{tabular}{lcl}
\hline & Initial & Extraction \\
\hline MANMADE & 1.000 & .807 \\
\hline NATURE & 1.000 & .644 \\
\hline ACTIVITY & 1.000 & .939 \\
\hline SOURCE OF LIFE & 1.000 & .955 \\
\hline CHARACTERISTIC & 1.000 & .882 \\
\hline PLACEMENT & 1.000 & .925 \\
\hline THOUGHT & 1.000 & .860 \\
\hline DIMENSION & 1.000 & .615 \\
\hline ELEMENT OF NA- & 1.000 & .901 \\
TURE & 1.000 & .933 \\
\hline HOUSEHOLD NEEDS & 1.000 & .901 \\
\hline COLOR &
\end{tabular}




\begin{tabular}{lll}
\hline CULTURE & 1.000 & .758 \\
\hline TEXTURE & 1.000 & .897 \\
\hline HOBBY & 1.000 & .915 \\
\hline $\begin{array}{l}\text { HUMAN RELATION- } \\
\text { SHIP }\end{array}$ & 1.000 & .904 \\
\hline
\end{tabular}

Peneliti mengurutkan variabel yang memiliki nilai tertinggi hingga yang paling rendah, yaitu variabel SOURCE OF LIFE $0.955=95.5 \%$ varian dari variabel ini dapat dijelaskan oleh faktor yang terbentuk, variabel ACTIVITY 0.939 $=93.9 \%$ varian dari variabel ini dapat dijelaskan oleh faktor yang terbentuk, variabel HOUSEHOLD NEEDS 0.933 $=93.3 \%$ varian dari variabel ini dapat dijelaskan oleh faktor yang terbentuk, variabel PLACEMENT $0.925=$ 92.5\% varian dari variabel ini dapat dijelaskan oleh faktor yang terbentuk, variabel HOBBY $0.915=91.5 \%$ varian dari variabel ini dapat dijelaskan oleh faktor yang terbentuk, variabel HUMAN RELATIONSHIP $0.904=90.4 \%$ varian dari variabel ini dapat dijelaskan oleh faktor yang terbentuk, variabel COLOR $0.901=90.1 \%$ varian dari variabel ini dapat dijelaskan oleh faktor yang terbentuk, variabel ELEMENT OF NATURE $0.901=90.1 \%$ varian dari variabel ini dapat dijelaskan oleh faktor yang terbentuk, variabel TEXTURE $0.897=89.7 \%$ varian dari variabel ini dapat dijelaskan oleh faktor yang terbentuk, variabel CHARACTERISTIC/APPEARANCE $0.882=88.2 \%$ varian dari variabel ini dapat dijelaskan oleh faktor yang terbentuk, variabel THOUGHT $0.860=86.0 \%$ varian dari variabel ini dapat dijelaskan oleh faktor yang terbentuk, variabel MANMADE $0.807=80.7 \%$ varian dari variabel ini dapat dijelaskan oleh faktor yang terbentuk, variabel CULTURE $0.758=75.8 \%$ varian dari variabel ini dapat dijelaskan oleh faktor yang terbentuk, variabel NATURE $0.644=64.4 \%$ varian dari variabel ini dapat dijelaskan oleh faktor yang terbentuk, variabel DIMENSION $0.615=$ $61.5 \%$ varian dari variabel ini dapat dijelaskan oleh faktor yang terbentuk. Dari persentase yang didapatkan, semakin kecil persentase variabel, maka semakin lemah hubungannya dengan faktor yang terbentuk.

Kemudian peneliti menemukan jumlah faktor yang terbentuk berdasarkan "Eigenvalue: > 1" (lihat Gambar 5)

Pada tabel total variance explained menunjukkan adanya 2 faktor yang terbentuk dari 15 variabel yang telah diproses dengan eigenvalue masing-masing faktor $>1$, yaitu faktor 1 dengan eigenvalue sebesar 11,230 dan variance $(74,867 \%)$, dan faktor 2 dengan eigenvalue sebesar 1,610 dan variance $(10,730 \%)$. Bila seluruh variabel dijumlahkan bernilai 15 , yakni sama dengan banyaknya variabel, maka $11,230 / 15 \times 100 \%=74,867 \%$ dan $1,610 / 15 \times 100 \%=10,730 \%$. Total varians apabila 15 variabel diekstrak menjadi 2 faktor adalah $74,867 \%+10,730 \%$ $=85,597 \%$, sehingga besarnya varian yang mampu dijelaskan oleh 2 faktor baru yang terbentuk adalah 85,597\% dan sisanya $14,403 \%$ dijelaskan oleh faktor lain yang tidak diteliti.

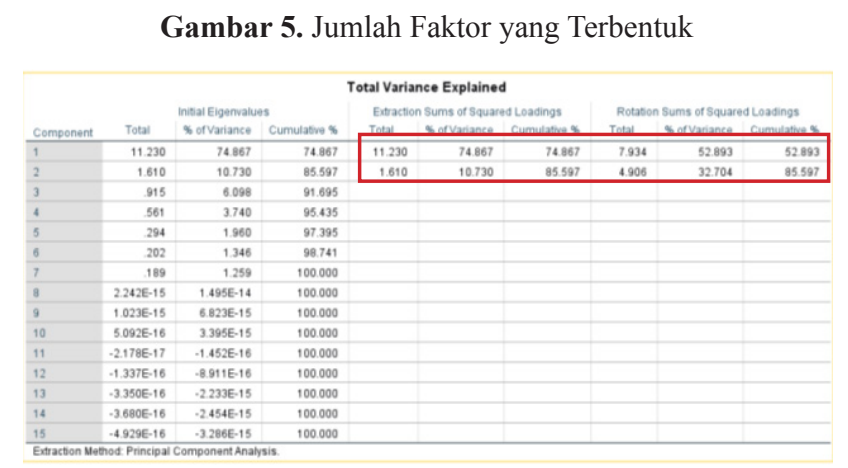

Tabel 3. Loading Factor dalam Tabel Rotated Component Matrix

Rotated Component Matrix ${ }^{\mathrm{a}}$

\begin{tabular}{l|c|c}
\hline & \multicolumn{2}{c}{ Component } \\
\hline & \multicolumn{1}{c}{1} & \multicolumn{1}{c}{2} \\
\hline HUMANRELATIONSHIP & .937 & .161 \\
\hline CHARACTERISTIC & .931 & .125 \\
\hline COLOR & .905 & .288 \\
\hline ELEMENTOFNATURE & .905 & .288 \\
\hline TEXTURE & .846 & .427 \\
\hline HOUSEHOLDNEEDS & .813 & .522 \\
\hline HOBBY & .810 & .510 \\
\hline ACTIVITY & .797 & .550 \\
\hline PLACEMENT & .735 & .621 \\
\hline CULTURE & .685 & .537 \\
\hline DIMENSION & .647 & .443 \\
\hline SOURCEOFLIFE & .413 & .886 \\
\hline MANMADE & .257 & .861 \\
\hline THOUGHT & .459 & .806 \\
\hline NATURE & .090 & .797 \\
\hline Beras
\end{tabular}

Berdasarkan gambar loading factor (lihat Tabel 3), peneliti menemukan 2 faktor yang didapatkan dari nilai $>0.5$ (berdasarkan tes KMO \& Bartlett's) pada tabel component 1 dan 2, yaitu faktor 1 (human relationship, characteristic, color, element of nature, texture, household needs, hobby, activity, placement, culture, dan dimension) dan faktor 2 (nature, thought, manmade dan source of life). Faktor 1 memiliki eigenvalue lebih besar dibandingkan faktor 2, yaitu 9.011, sedangkan faktor 2 memiliki eigenvalue sebesar 6.09, sehingga pengaruh faktor 1 jauh lebih besar daripada faktor 2. Kedua faktor tersebut memiliki nama dimensi yang berbeda, F1 memiliki nama dimensi human relationship, characteristic, color, element of nature, texture, household needs, hobby, activity, placement, culture, dan dimension dan F2 memiliki makna dimensi nature, thought, manmade dan source of life. Dimensi human relationship, characteristic, color, element of nature, texture, household needs, hobby, activity, placement, culture, dan dimension menghasilkan dimensi baru yang dapat mewakili kesebelas dimensi tersebut, yaitu harmoni (harmony) dengan nilai eigenvalue sebesar 9.011 yang diperkuat 
dengan adanya dimensi lain, seperti solidarity. Kemudian dimensi nature, thought, manmade dan source of life menghasilkan dimensi baru yang dapat mewakili keempat dimensi tersebut, yaitu ketenangan (serenity) dengan nilai eigenvalue sebesar 6.09 dan diperkuat dengan adanya dimensi lain, seperti calmness, quietness dan peace of mind. Kedua dimensi baru ini (lihat Tabel 4) dapat merepresentasikan pemikiran pelukis Jelekong dalam proses menggambar sketsa.

Tabel 4. Faktor Ideasi dalam Proses Kreasi Seniman Lukis Jelekong

\begin{tabular}{|c|c|c|c|}
\hline & Dimension & & Factor \\
\hline Factor & Name & Eigenvalue & Name \\
\hline \multirow{13}{*}{$\mathrm{F} 1$} & Human & \multirow{13}{*}{9.011} & \multirow{13}{*}{$\begin{array}{c}\text { Harmoni } \\
\text { (Harmony, } \\
\text { Solidarity) }\end{array}$} \\
\hline & relationship, & & \\
\hline & Characteristic, & & \\
\hline & Color, & & \\
\hline & Element of & & \\
\hline & nature, & & \\
\hline & Texture, & & \\
\hline & Household & & \\
\hline & needs, Hobby, & & \\
\hline & Activity, & & \\
\hline & Placement, & & \\
\hline & Culture, & & \\
\hline & Dimension & & \\
\hline \multirow{4}{*}{$\mathrm{F} 2$} & Nature, & \multirow{4}{*}{6.09} & \multirow{4}{*}{$\begin{array}{c}\text { Ketenangan } \\
\text { (Serenity, } \\
\text { Quiteness, } \\
\text { Calmness) }\end{array}$} \\
\hline & Thought, & & \\
\hline & Manmade, & & \\
\hline & Source of life. & & \\
\hline
\end{tabular}

REPRESENTASI 15 DIMENSI PADA FAKTOR IDEASI DALAM PROSES KREASI SENIMAN LUKIS JELEKONG

Berdasarkan hasil analisis gambar sketsa yang telah dipaparkan sebelumnya, peneliti mendapatkan lima belas dimensi yang berbeda dalam proses kreasi seniman lukis Jelekong, yaitu placement, element of nature, source of life, activity, thought, texture, manmade, human relationship, color, nature, dimension, culture, household needs, characteristic dan hobby. Kelima belas dimensi ini dapat merepresentasikan hasil gambar sketsa dan proses kreasi seniman lukis Jelekong yang terjadi pada saat menggambar sketsa.

Dimensi placement diindikasikan melalui seringnya pelukis memperhatikan komposisi objek gambar dengan menempatkan objek gunung di tengah gambar, aliran sungai di tengah gambar yang dijadikan pembatas dan objek pohon di sisi kanan dan kiri gambar. Pada saat melukis, peneliti melihat bahwa komposisi ini jarang sekali berubah dalam melukis lukisan pemandangan alam. Tampaknya, komposisi ini merupakan hasil pembelajaran seni lukis dari pelukis sebelumnya, sehingga komposisi yang terbentuk selalu sama dan tidak pernah berubah selama berlangsungnya kegiatan melukis di Jelekong. Kemungkinan komposisi ini juga akan terus diajarkan kepada generasi seniman lukis selanjutnya dan menjadi karakter khas dari lukisan Jelekong.

Dimensi element of nature diindikasikan melalui seringnya menggambarkan unsur alam tambahan, seperti bebatuan dan hewan dalam lukisan pemandangan alam. Jika dikaitkan dengan proses kreasi seniman lukis Jelekong, unsur alam ini juga merupakan hasil pembelajaran seni lukis dari pelukis sebelumnya, yang mana pelukis sebelumnya sering melakukan penambahan unsur alam pada karya lukisnya, sehingga para pelukis muda meniru apa yang digambarkan pelukis senior dan menghasilkan gambar yang serupa.

Dimensi source of life diindikasikan melalui adanya sumber kehidupan manusia, seperti gunung, aliran sungai, laut dan matahari. Pelukis seringkali menggambar objek gunung dan aliran sungai dalam gambar pemandangan alam dalam gambar sketsanya, tampaknya objek ini juga merupakan hasil pembelajaran seni lukis dari pelukis sebelumnya yang mengajarkan penggambaran lukisan pemandangan alam diharuskan menggunakan objek gunung dan aliran sungai, meskipun pada kenyataannya area persawahan di Jelekong tidak memiliki aliran sungai yang serupa dengan gambar lukisan pemandangan Jelekong.

Dimensi activity diindikasikan melalui adanya aktifitas makhluk hidup, seperti nelayan sedang berlayar dan beraktifitas di pinggir pantai maupun di rumah pada sore hari, serta rusa yang sedang memakan rumput. Namun peneliti melihat pelukis jarang sekali menggambarkan aktifitas makhluk hidup dalam gambar sketsa maupun karya lukis yang sering diproduksi. Tampaknya pelukis ingin memberikan kesan ruang yang luas pada gambar, sehingga seringkali gambar ataupun lukisan yang dihasilkan tidak terlihat aktifitas makhluk hidup di dalamnya dan hanya menonjolkan alam Jelekong. Meskipun demikian, peneliti masih dapat menemukan penggambaran aktifitas makhluk hidup di beberapa hasil gambar sketsa seniman lukis Jelekong.

Dimensi thought diindikasikan melalui seringnya pelukis menuangkan ingatan akan suasana alam, seperti ingatan akan kesejukan hutan belantara, suasana sejuk pegunungan dan pemandangan laut. Hal ini dapat dilihat dari hasil transkrip ucapan pelukis pada saat menceritakan idenya selalu mengenai apa yang sedang diingat dan dibayangkan saat proses percobaan menggambar sketsa berlangsung. Dimensi ini cukup berpengaruh dalam proses kreasi seni- 
man lukis Jelekong pada saat menghasilkan sebuah karya. Jika dikaitkan dengan alih pengetahuan yang terjadi di Jelekong, dimensi ini merupakan ingatan seniman akan tema yang diajarkan pelukis sebelumnya maupun tema yang sering dilihat pada saat proses pembelajaran.

Dimensi texture diindikasikan melalui adanya penanda tekstur pohon dengan menggunakan perbedaan garis dan titik hitam. Pelukis seringkali memberikan tanda berupa lingkaran hitam tebal pada batang pohon dan juga menggunakan garis zig-zag maupun bergelombang untuk menggambarkan batang pohon. Tampaknya hal ini merupakan hasil dari alih pengetahuan yang terjadi di dalam komunitas pelukis untuk memberikan tanda pada batang pohon yang akan diberikan tekstur.

Dimensi manmade diindikasikan melalui adanya objek hasil buatan tangan manusia, seperti rumah, saung, perahu dan jembatan. Objek rumah dan saung seringkali digambarkan pada lukisan pemandangan gunung, sedangkan perahu dan jembatan seringkali digambarkan pada lukisan pemandangan laut. Objek gambar ini tampaknya juga merupakan hasil alih pengetahuan dari pelukis sebelumnya yang seringkali menggambarkan objek ini dalam lukisan pemandangan. Peneliti melihat seringnya pelukis menggambar objek tersebut ke dalam lukisan pemandangan dengan penempatan yang hampir mirip dengan karya yang telah dilukis sebelumnya.

Dimensi human relationship diindikasikan melalui jarak rumah yang berdekatan, seringnya pelukis menggambar objek pohon sebagai pelindung dan nelayan yang saling bekerjasama yang menimbulkan kesan kekeluargaan.

Dimensi color diindikasikan melalui keinginan pelukis untuk memberikan warna pada setiap objek gambar. Para seniman seringkali membayangkan warna yang diberikan pada objek sawah untuk membedakan sawah yang telah dipanen dengan sawah yang masih baru saja ditumbuhi padi, selain itu juga untuk membedakan padi yang siap dipanen dengan padi yang masih belum dapat dipanen.

Dimensi nature diindikasikan melalui penggambaran alam Jelekong yang indah dengan menggambarkan pemandangan gunung dan sawah yang seringkali dikelilingi banyak pohon. Selain itu, pelukis juga menggambar pemandangan laut dan hutan belantara yang bukan merupakan alam Jelekong, kemungkinan kedua pemandangan tersebut merupakan hasil ingatan pelukis akan tema lukisan yang diajarkan oleh pelukis sebelumnya.

Dimensi dimension diindikasikan melalui seringnya penempatan objek berjumlah dua di sisi kanan dan kiri yang menyebabkan komposisi gambar yang seimbang. Selain itu, pelukis juga seringkali memperhatikan ruang gambar, jika ruang gambar terlihat sempit, maka seniman Jelekong tidak begitu banyak menggambarkan objek. Namun jika ruang gambar telihat luas, maka seniman Jelekong menggambar objek dengan ukuran yang lebih besar dan menambahkan jumlah objek gambar.

Dimensi culture diindikasikan melalui adanya keragaman jenis pohon dan perbedaan bentuk tubuh rusa dan kuda yang dapat membedakan jenis kelamin keduanya, seperti adanya tanduk di kepala rusa yang menandakan rusa jantan, serta tubuh salah satu kuda yang lebih besar dan berotot yang menandakan kuda jantan. Jenis pohon yang seringkali digambarkan adalah pohon kelapa dan beringin, tampaknya kedua pohon ini seringkali digambar oleh pelukis sebelumnya, sehingga pola ini terus diterapkan hingga saat ini. Selain itu, dimensi culture juga dapat diindikasi melalui penggambaran pasar Bali yang memiliki perbedaan suasana dengan pasar Jelekong.

Dimensi household needs diindikasikan melalui adanya perbedaan profesi, seperti nelayan dan petani. Adanya profesi yang digambarkan pada gambar sketsa seniman lukis Jelekong dapat menimbulkan kesan bahwa manusia harus bekerja untuk memenuhi kebutuhan hidup sehari-hari. Profesi yang digambarkan juga disesuaikan dengan kondisi masyarakat yang tinggal di desa dan dekat dengan alam.

Dimensi characteristic diindikasikan melalui adanya garis pemisah vertikal dan diagonal untuk membedakan langit dan laut, kanan dan kiri, serta laut dan daratan. Dimensi ini juga dapat menunjukkan adanya karakter khas dari lukisan Jelekong yang ditandai dengan adanya tema lukisan Jelekong yang sudah diwariskan secara turun-temurun.

Dimensi hobby diindikasikan melalui adanya hobi seorang anak menaiki kerbau pada saat menemani ayahnya bekerja di sawah. Dimensi ini jarang sekali digunakan pada gambar sketsa dikarenakan para seniman jarang sekali menggambar aktifitas makhluk hidup dan lebih sering menonjolkan suasana alamnya saja. Pada proses kreasi seniman Jelekong, para seniman memproduksi seni lukis seperti melakukan hobi tanpa adanya beban dan terlihat sangat santai. Para seniman dapat merokok, minum kopi, berbincang-bincang satu sama lain dan beristirahat kapapun yang mereka inginkan.

\section{DOMINASI GREEN DAN PICTURE DALAM LEVEL PROSES KREASI SENIMAN LUKIS JELEKONG}

Berdasarkan hasil analisis verbal yang telah dipaparkan sebelumnya, peneliti mendapatkan kata green dan picture sebagai makna asosiatif dengan nilai makna asosiatif tertinggi yang mendominasi ucapan sepuluh seniman Jelekong. Kata green merepresentasikan level proses kreasi seniman Jelekong pada penggambaran objek yang hijau, sedangkan kata picture merepresentasikan level proses kreasi seniman Jelekong pada gambar. Kedua kata ini pada seluruh subjek yang diteliti memiliki nilai makna asosiatif 
tertinggi, yang berarti kedua kata ini seringkali muncul dalam proses kreasi seniman lukis Jelekong.

Pada proses kreasi seniman lukis Jelekong, Odin dan pelukis senior lainnya selalu mengajarkan lukisan pemandangan saat awal pembelajaran seni lukis di Jelekong, sehingga banyak pelukis yang ahli dalam menggambar lukisan pemandangan. Selain itu, pelukis seringkali menambahkan unsur hijau dalam tema lukisan lainnya, seperti pada lukisan ikan koi, kuda, pasar Bali, bunga, dan lain sebagainya, hal ini turut mempengaruhi level proses kreasi seniman lukis Jelekong yang dapat dilihat dari dominasi kata green pada hasil analisis verbal seniman Jelekong. Level proses kreasi seniman Jelekong pada kata green juga dapat dilihat dari hasil gambar sketsanya yang seringkali menggambarkan objek hijau, seperti pohon dan tanaman liar pada gambar untuk menampilkan kesan rindang dan sejuk. Berdasarkan hasil transkrip ucapan, banyak pelukis yang membayangkan suasana sejuk suatu tempat pada saat menggambar sketsa. Hal ini juga dapat memperkuat munculnya kata green yang mendominasi level proses kreasi seniman Jelekong.

Sedangkan kata picture pada proses kreasi seniman lukis Jelekong dapat terlihat dari hasil gambar sketsa yang seringkali terfokus pada unsur-unsur visual untuk menarik perhatian penikmat karyanya. Seniman lukis Jelekong seringkali memperhatikan komposisi yang seimbang dan alam yang indah, hal inilah yang mempengaruhi level proses kreatif seniman lukis Jelekong yang didominasi oleh kata picture. Selain itu, berdasarkan hasil transkrip ucapan seniman lukis Jelekong seringkali berbicara mengenai ketertarikannya kepada objek yang digambar, keinginan para pelukis untuk menambahkan warna dalam gambar sketsa nya, serta ingatan para pelukis akan masa lalu maupun suasana nyaman suatu tempat. Ketiga hal tersebut dapat merepresentasikan pemikiran seniman lukis Jelekong yang selalu memperhatikan hasil gambarnya.

\section{HARMONI DAN KETENANGAN DALAM PROSES KREASI SENIMAN LUKIS JELE- KONG}

Berdasarkan hasil data statitistik, peneliti mendapatkan dua faktor ideasi dalam proses kreasi seniman lukis Jelekong, yakni harmoni dan ketenangan. Kata harmoni (harmony) terbentuk berdasarkan faktor human relationship, characteristic, color, element of nature, texture, household needs, hobby, activity, placement, culture dan dimension yang saling berhubungan dan membentuk dua faktor, yaitu solidarity dan harmony. Dari kedua faktor yang terbentuk, peneliti memilih faktor harmoni karena dianggap lebih sesuai dengan proses kreasi seniman lukis Jelekong, sedangkan kata ketenangan terbentuk berdasarkan faktor nature, thought, manmade dan source of life yang saling berhubungan dan membentuk tiga faktor, yakni serenity, quietness dan calmness. Dari ketiga faktor yang terbentuk, peneliti memilih faktor ketenangan karena dianggap lebih sesuai dengan proses kreasi seniman lukis Jelekong.

Faktor harmoni yang merepresentasikan human relationship pada gambar sketsa dengan penggambaran rumah yang berdekatan, serta adanya hubungan ayah dan anak pada penggambaran petani dan anaknya yang sedang menemaninya di sawah. Faktor harmoni juga merepresentasikan characteristic pada gambar sketsa, yang mana para seniman seringkali menempatkan objek berjumlah dua dan penggambaran alam Jelekong yang indah. Faktor harmoni yang merepresentasikan color pada gambar sketsa, yakni penggunaan warna yang berbeda untuk membedakan objek jauh dan dekat, serta memberi bayangan pada objek. Faktor harmoni dalam element of pada gambar sketsabdirepresentasikan dengan penggambaran alam yang ideal dengan adanya langit, bentuk figuratif dan benda-benda alam. Faktor harmoni yang merepresentasikan texture pada gambar sketsa, yakni penggunaan garis yang berbeda namun tetap dapat menghasilkan komposisi yang seimbang, seperti garis bergelombang dan zig-zag untuk menandai tekstur yang akan digunakan pada sebuah objek.

Faktor harmoni dalam household needs pada gambar sketsa direpresentasikan dengan adanya penggambaran aktifitas nelayan yang bekerja untuk mencukupi kehidupannya. Faktor harmoni dalam hobby pada gambar sketsa direpresentasikan dengan penggambaran aktifitas objek yang sedang menaiki kerbau. Faktor harmoni dalam activity pada gambar sketsa direpresentasikan dengan penggambaran aktifitas nelayan di laut dan petani di sawah. Faktor harmoni dalam placement pada gambar sketsa direpresentasikan dengan adanya komposisi yang seimbang. Faktor harmoni dalam culture pada gambar sketsa direpresentasikan dengan penggambaran tema lukisan Jelekong yang dilakukan berulang dan menghasilkan objek yang sama. Faktor harmoni dalam dimension pada gambar sketsa direpresentasikan melalui penggambaran objek berjumlah genap.

Sedangkan faktor ketenangan dalam nature pada gambar sketsa direpresentasikan dengan suasana yang sepi dengan tidak adanya alam yang rusak dan suasana yang sejuk dengan banyaknya pohon berdaun lebat. Faktor ketenangan dalam thought pada gambar sketsa direpresentasikan dengan ide yang dituangkan kepada gambar berupa ingatan seniman akan suasana sejuk alam. Faktor ketenangan dalam manmade pada gambar sketsa direpresentasikan dengan seringnya menggambar satu rumah, saung dan jembatan. Faktor ketenangan dalam source of life pada gambar sketsa direpresentasikan dengan menggambar satu matahari dan satu gunung pada gambar sketsa.

Berdasarkan penjabaran temuan faktor ideasi yang dikaitkan dengan lima belas dimensi pembentuknya, sepuluh pelukis yang diteliti dalam pikirannya yang direpresentasikan dengan makna asosiatif yang mengarah kepada 
dimensi harmoni dengan eigenvalue sebesar 9.011 yang diindikasikan dari keberadaan identitas keharmonian tersebut dengan jarak rumah yang digambarkan berdekatan, penempatan objek yang umumnya berjumlah dua di sisi kanan dan kiri, penggunaan warna yang berbeda antara objek jauh dan dekat, pemandangan alam yang ideal dengan adanya awan, bentuk figuratif dan benda-benda alam lainnya, penggunaan garis yang berbeda pada setiap objek untuk memberikan tekstur, penggambaran perbedaan profesi, perbedaan aktifitas, serta adanya komposisi objek yang seimbang meskipun menggambarkan banyak objek. Ketika para pelukis menggambar sketsa juga mempertimbangkan ketenangan dengan nilai eigenvalue sebesar 6.09 yang diindikasikan melalui penggambaran suasana yang sepi dengan tidak adanya unsur alam yang rusak, suasana yang sejuk dengan banyaknya pohon berdaun lebat, adanya ingatan seniman akan suasana alam yang sejuk dan tenang, serta gambar-gambar dengan ruang yang luas, seperti hanya terdapat satu rumah dan sangat jarang menggambar banyak makhluk hidup.

\section{SIMPULAN}

Faktor harmoni pada ruang pembelajaran melukis yang seringkali dilakukan bersama-sama mengalami sintesa mental dasar yang dapat diindikasikan melalui gambar sketsa pelukis dengan penggambaran pemandangan alam yang indah, penempatan objek berjumlah dua di sisi kiri dan kanan, adanya komposisi objek yang seimbang, serta penggambaran alam yang ideal, yaitu terdapat langit, bentuk figuratif dan benda-benda alam lainnya yang kurang lebih sesuai dengan kondisi alam aslinya. Kemudian faktor ketenangan pada ruang pembelajaran melukis yang seringkali dalam keadaan tenang dan santai mengalami sintesa mental dasar yang dapat diindikasikan melalui penggambaran suasana yang sepi dengan tidak adanya unsur alam yang rusak, seperti kekeringan, namun tercermin suasana yang sejuk dengan banyaknya pohon berdaun lebat, serta penggambaran ruang yang luas, seperti hanya terdapat satu rumah dan sangat jarang menggambar banyak orang.

Faktor ideasi dalam proses kreasi seniman lukis Jelekong cenderung mempraktikkan peniruan atau mencontoh karya yang telah dibuat sebelumnya dari seringnya pelukis menggambar objek yang mirip dengan objek gambar lukisan yang diproduksi setiap hari. Peneliti sangat jarang menemukan unsur kebaruan dalam gambar yang menyebabkan seringnya faktor harmoni dan ketenangan ditemukan dalam setiap karya. Kedua faktor ini membentuk ciri khas tersendiri dalam proses kreasi seniman lukis Jelekong agar karya yang dihasilkan tetap laku di pasaran.

\section{DAFTAR RUJUKAN}

Andriyanto. (2012): Pewarisan seni lukis Jelekong; sebuah kajian pada seniman lukis di kabupaten Jelekong kecamatan Baleendah kabupaten Bandung, Tesis Magister Program Pascasarjana Institut Seni dan Budaya Indonesia, Bandung, $81-109$.

Cho, Y. dan Egan, T. M. (2010). The state of the art of action learning research. Advances in Developing Human Resources, 12 (2), 163 - 180. Diunduh 12 September 2019 dari www.researchgate.net.

Finke, R. A. \& Slayton, K. (1988). Explorations of creative visual synthesis in mental imagery. Memory \& Cognition, 16 (3), $252-257$.

Finke, R. A. (1980). Levels of equivalence in imagery and perception. Psychological Review, 87 (2), 113 - 132.

Kikuchi, Y. (2004). Japanese modernisation and mingei theory; cultural nationalism and oriental orientalism. Taylor \& Francis e-Library, 52-58. Diunduh 21 Maret 2019 dari https://epdf.pub.

Loughlin, S., Grossnickle, E., Dinsmore, D., dan Alexander, P. (2015). "Reading" paintings: evidence for trans-symbolic and symbol-specific comprehension processes. Cognition and Instruction, 33 (3), 257 - 293.

Rukmana, N. K. (2017): Identitas estetik pada seni lukis Jelekong, Tesis Magister Program Pascasarjana Institut Seni dan Budaya Indonesia, Bandung, 25- 47.

Runco, M.A dan Pritzker, S. R. (1999). Encyclopedia of creativity. Academic Press, 2, 1-3.

Serrat, O. (2017). Action learning, Knowledge Solutions, $589-594$

Triyanto. (2015): Mata kuliah estetika Barat, diperoleh dari situs internet https://www.academia.edu/. Diunduh pada tanggal 9 Januari 2020.

Kosyim (70th), Pelukis, wawancara pada tanggal 12 September 2019 di rumahnya, Kampung Giriharja, Kecamatan Baleendah, Kabupaten Bandung. 